\title{
MANAGEMENT OF NITROGEN FERTILIZATION ON AGRONOMIC AND NUTRITIONAL CHARACTERISTICS IN SECOND CROP CORN
}

\author{
MANEJO DA FERTILIZAÇÃO NITROGENADA SOBRE CARACTERÍSTICAS \\ AGRONÔMICAS E NUTRICIONAIS EM MILHO DE SEGUNDA SAFRA
}

\author{
Daiane de Souza BUENO ${ }^{1 *}$; Sebastião Ferreira de LIMA; Matildes BLANCO; \\ Paulo Carteri CORADI ${ }^{2}$ \\ 1. Federal University of Mato Grosso do Sul (UFMS), Chapadão do Sul Campus, MS, Brazil. dayah_bueno@hotmail.com; Federal \\ University of Santa Maria (UFSM), Cachoeira do Sul Campus, RS, Brazil. paulo.coradi@ufsm.br
}

\begin{abstract}
Fertilization management, mainly nitrogen, is one of the factors that most directly affect corn grain yield. Nitrogen dynamics in the soil is quite complex and its main source currently used in corn production, the urea, undergo intense losses in its conventional form, mainly by volatilization and leaching. Thus, the aim of this study was to assess the effect of forms, sources, and times of nitrogen application on the second crop corn. The experiment was conducted in 2016 in the Fundação Chapadão, Chapadão do Sul, MS, Brazil. The sources conventional urea, polymer-coated urea, and foliar $\mathrm{N}$ (8 treatments) were used as follows: control (without $\mathrm{N}$ addition), conventional urea (single in V3 and split in V3 and V6), polymer-coated urea (single in V3 and split in V3 and V6), conventional urea + foliar N (conventional urea in V6 and foliar in preflowering), polymer-coated urea + foliar $\mathrm{N}$ (polymer-coated urea in V6 and foliar in pre-flowering), and foliar $\mathrm{N}$ (split in V6 and pre-flowering). The variables stem diameter, ear index, ear length, number of grains per row, number of rows per ear, plant height, first ear height, leaf chlorophyll index, leaf $\mathrm{N}$ index, leaf values of $\mathrm{Ca}$, $\mathrm{Mg}, \mathrm{Fe}, \mathrm{Zn}, \mathrm{Mn}$, and $\mathrm{Cu}, 100$-grain weight, and grain yield were assessed. Nitrogen application in the form of conventional urea, polymer-coated urea, and foliar $\mathrm{N}$ (single or split) for second crop corn does not result in distinct benefits for the crop. Thus, attention should be paid to the commercialization of the product, which has prices established according to nitrogen forms, but without result, for example, in grain yield, which in fact will compose the producer income. The applied nitrogen form and mode of application were positive only to increase the contents of $\mathrm{Ca}, \mathrm{Mg}, \mathrm{Zn}$, and $\mathrm{Mn}$ in the leaves of second crop corn. Ca was favored by the use of conventional urea and split conventional urea, $\mathrm{Mg}$ and $\mathrm{Mn}$ were only benefited by foliar $\mathrm{N}$ application, and $\mathrm{Zn}$ was benefited by the use of conventional urea, split conventional urea, conventional urea + foliar $\mathrm{N}$, and polymer-coated urea+foliar $\mathrm{N}$.
\end{abstract}

KEYWORDS: fertilization, $\mathrm{N}$ sources, foliar application.

\section{INTRODUCTION}

Corn (Zea mays L.) is the second mostproduced grain in Brazil, just after soybean. In the $2016 / 17$ season, a production of 97.8 million tons of grain was reached in an area of 17.6 million hectares (CONAB, 2018). It is one of the most important crops in the world and considering the global problems of food scarcity, reduction of arable land, excessive use of fertilizers, and environmental contamination, priority should be given to increase yield and fertilizer use efficiency (MA et al., 2014; WANG et al., 2014).

In Brazil, corn is commercially grown in the first and second crops and although the volume of corn produced in the second crop has recently exceeded the volume produced in the first crop, its yield is still lower (CONAB, 2018), which is due to factors such as reduction of water availability and nutritional management. In order to reach higher yield levels, fertilizer application efficiency needs to be increased (BIESDORF et al., 2016), focusing mainly on nitrogen $(\mathrm{N})$, which has an use of around $50 \%$ when applied in the mineral form due to losses in the environment (KARLEN et al., 1998), mainly by volatilization and leaching (SAIKIA; JAIN, 2007).

Nitrogen is an essential nutrient in the initial crop stage since it acts on its vegetative development, more specifically on cell division, and on the photosynthetic process of the plant (FARINELLI and LEMOS, 2010). In soil, $\mathrm{N}$ is available in two forms, the nitric $\left(\mathrm{NO}_{3}{ }^{-}\right)$and ammoniacal $\left(\mathrm{NH}_{4}^{+}\right)$(BIESDORF et al., 2012), which are absorbed by plants. Plants absorb $\mathrm{N}$ throughout their vegetative cycle, which occurs as a function of the number of roots and absorption rate. During the vegetative growth occurs a high rate of nitrate reduction and formation of amino acids in the leaf. In the reproductive stage, nitrate reduction 
decreases due to $\mathrm{N}$ remobilization from leaves to inflorescences, increasing the concentration of amino acids in the phloem, reducing the absorption rate of $\mathrm{NO}_{3}{ }^{-}$by the roots (FONTOURA; BAYER, 2010).

The increase in corn yield in recent years is closely related to the excessive use of mineral fertilizers. An excessive $\mathrm{N}$ application may result in its low use by the crop and high environmental losses, affecting air, water, and human health quality (GOULDING et al., 2008). Therefore, alternatives should be sought to increase $\mathrm{N}$ use efficiency, not only to minimize environmental risks but also to reduce the producer costs (WANG et al., 2011).

Among the strategies to minimize losses and increase $\mathrm{N}$ use efficiency is the split of nitrogen fertilization or use of controlled release fertilizers, providing nitrogen to the plants in the stages of higher demand, thus minimizing losses through volatilization and leaching (CANTARELLA; MARCELINO, 2008). A controlled release fertilizer is an alternative to common fertilizers since it increases $\mathrm{N}$ absorption efficiency, reducing losses to the environment. However, producer acceptance is limited due to the lack of experience and high costs (MEDINA et al., 2008).

The mode of $\mathrm{N}$ application is also essential to increase its use efficiency. Usually, foliar $\mathrm{N}$ application is complementary to that applied via soil since $\mathrm{N}$ can be provided at the beginning of plant development, as well as at later stages, when the demand becomes greater. The foliar route is also interesting for fast responses to the mineral and control nutritional deficiencies in stages in which the application via soil is inefficient (GAZOLA et al., 2014).

The search for techniques that reduce losses and increase the efficiency of $\mathrm{N}$ fertilization, as well as the determination of the best time to the application of each nitrogen source is essential for the proper crop development (KAPPES et al., 2009). Thus, this study aimed to assess the forms, sources, and times of $\mathrm{N}$ application in the second crop corn.

\section{MATERIAL AND METHODS}

The experiment was conducted under field conditions in the second crop of the 2015/16 season at the experimental unit of the Fundação Chapadão located in Chapadão do Sul, MS, Brazil, at the geographical coordinates $18^{\circ} 48^{\prime} 459^{\prime \prime} \mathrm{S}$ and $52^{\circ} 36^{\prime} 003^{\prime \prime} \mathrm{W}$, with an altitude of approximately $820 \mathrm{~m}$. Regional climate is classified Aw according to Köppen, i.e. a tropical humid climate with an average temperature around $29{ }^{\circ} \mathrm{C}$ and annual average precipitation of $1,850 \mathrm{~mm}$ concentrated in the summer and drought in the winter (CUNHA et al., 2013). The soil of the experimental area is characterized as a dystrophic Red Latosol (Oxisol) with a clayey textured latosolic B-horizon. Soil physical and chemical analysis at a depth of 0.00 to $0.20 \mathrm{~m}$ was performed before experiment setup and presented a predominantly clayey soil with a $\mathrm{pH}$ of 5.3 , calcium of $2.8 \mathrm{cmol}_{\mathrm{c}} \mathrm{dm}^{-3}$, magnesium of 1.1 $\mathrm{cmol}_{\mathrm{c}} \mathrm{dm}^{-3}$, aluminum of $0.05 \mathrm{cmol}_{\mathrm{c}} \mathrm{dm}^{-3}$, potassium of $209.7 \mathrm{mg} \mathrm{dm}^{-3}$, phosphorus of $37.4 \mathrm{mg}$ $\mathrm{dm}^{-3}$, sulfur of $3.3 \mathrm{mg} \mathrm{dm}^{-3}$, organic matter of 38.8 $\mathrm{g} \mathrm{dm}^{-3}$, and CEC of $8.2 \mathrm{cmol}_{\mathrm{c}} \mathrm{dm}^{-3}$. The micronutrient contents found in the area were boron of $0.14 \mathrm{mg} \mathrm{dm}^{-3}$, copper of $1.50 \mathrm{mg} \mathrm{dm}^{-3}$, iron of $89.00 \mathrm{mg} \mathrm{dm}^{-3}$, manganese of $21.70 \mathrm{mg} \mathrm{dm}^{-3}$, and zinc of $8.30 \mathrm{mg} \mathrm{dm}^{-3}$. The precipitation regime for the period of implantation and development of the crop was up to $313 \mathrm{~mm}$ in February and a minimum of $37 \mathrm{~mm}$ in June 2016.

The experimental design was a randomized block design with eight treatments and four replications. Treatments (Table 1) consisted of $\mathrm{N}$ application in the form of urea with different combinations: common urea or slow release urea, application via soil or foliar, and application at different stages of plant development. Nitrogen dose was $135 \mathrm{~kg} \mathrm{ha}^{-1}$ through the use of three products with the following amounts: $300 \mathrm{~kg} \mathrm{ha}$ of conventional urea $(45-00-00), 300 \mathrm{~kg} \mathrm{ha}^{-1}$ of polymer-coated urea $\left(\right.$ Kimcoat $\left.^{\circledR}\right)(44-00-00)$, and 9 $\mathrm{L} \mathrm{ha}^{-1}$ of $\mathrm{NTOP}^{\circledR}$ (foliar, 30\% N). The amounts of Kimcoat $^{\circledR}$ and $\mathrm{NTOP}^{\circledR}$ are compatible to equal the amount of $\mathrm{N}$ contained in the conventional urea, i.e. $1 \mathrm{~kg}$ of urea equals to $1 \mathrm{~kg}$ of Kimcoat ${ }^{\circledR}$ and $1 \mathrm{~L}$ of $\mathrm{NTOP}^{\circledR}$ equals to $15 \mathrm{~kg}$ of N.

The plot consisted of seven plant rows of $5.5 \mathrm{~m}$ in length, spaced $0.90 \mathrm{~m}$ from each other, totaling 32 plots. Sowing fertilization was carried out in the furrow using $90 \mathrm{~kg} \mathrm{ha}^{-1}$ of $\mathrm{P}_{2} \mathrm{O}_{5}$ (simple superphosphate) and $50 \mathrm{~kg} \mathrm{ha}^{-1}$ of $\mathrm{K}_{2} \mathrm{O}$ (potassium chloride). Nitrogen was not applied in the sowing aiming at assessing the topdressing fertilizations.

The history of the experimental area shows the following crop sequence, always considering the first/second crop, respectively: in 2013/2014, soybean/corn; in 2014/2015, bean/corn; and in 2015/2016, Urochloa ruziziensis/corn, which was used in this experiment. The corn hybrid P3456H, which has resistance to Lepidoptera (caterpillars), was used in the experiment. Sowing was performed on March 22, 2016, using a population of 55 thousand plants per hectare, with five plants per linear meter. 
Table 1. Treatments used in corn cultivation according to the phenological stage

\begin{tabular}{lll}
\hline Treatment & Application time \\
\hline T1 & Control & - \\
T2 & Conventional urea & Single application in V3 \\
T3 & Conventional urea & Split application in V3 and V6 \\
T4 & Polymer-coated urea & Single application in V3 \\
T5 & Polymer-coated urea & Split application in V3 and V6 \\
T6 & Conventional urea + foliar N & Conventional urea in V6 and foliar N in pre-flowering \\
T7 & Polymer-coated urea + foliar N & Polymer-coated urea in V6 and foliar N in pre-flowering \\
T8 & Foliar N & Split in V6 and pre-flowering \\
\hline
\end{tabular}

V3 and V6 = Phenological stages for the corn crop.

The following agronomic characteristics were assessed: stem diameter, ear index, ear length, number of grains per row, number of rows per ear, 100-grain weight, plant height, first ear height, and relative indices of chlorophyll a, b, and total. Stem diameter was assessed by measuring ten plants in the useful area of each plot. For this, the second internode was measured with a caliper (ROSSETTI and CENTURION, 2013). The ear index was assessed by counting the ears of ten plants in the useful area of each plot and averaged. For ear length, the length of ten ears was measured at random in each plot at the final stage of crop development using a graduated ruler. The number of grains per row and rows per ears was counted in ten ears randomly collected from each plot. For the variable 100-grain weight, eight samples of 100 grains were taken per plot and averaged.

Plant height and first ear height were measured in five plants per plot using a graduated ruler. Plant height was measured from the ground to the insertion point of the last leaf blade. Similarly, the first ear height was measured from the ground to the insertion point of the first ear (LUNELLI et al., 2010).

Leaf chlorophyll index was determined using a portable chlorophyll meter (CFL 1030 Clorofilog) by the SPAD method. For the measurement, the first expanded leaf was used in the first assessment (before $\mathrm{N}$ application), while the opposite leaf to the ear was used in the second assessment (after $\mathrm{N}$ application). The ratios of chlorophyll a, chlorophyll b, and total chlorophyll (a $+b$ ) were measured and expressed in dimensionless units, called leaf chlorophyll index (LCI).

For the assessment of the leaf content of nitrogen $(\mathrm{N})$, calcium $(\mathrm{Ca})$, magnesium $(\mathrm{Mg})$, iron $(\mathrm{Fe})$, zinc $(\mathrm{Zn})$, manganese $(\mathrm{Mn})$, and copper $(\mathrm{Cu})$, five leaves were collected at random before and after $\mathrm{N}$ topdressing applications. In the first collection, the first expanded leaf was used, while in the second collection, at the full flowering stage, the opposite leaves below the ear were used. In both cases, the leaves were conditioned in paper bags with identification and dried in a forced air circulation oven with an average temperature of 65 ${ }^{\circ} \mathrm{C}$ until reaching a constant mass. After drying, the leaves were ground, including the midrib, and then submitted to sulfuric digestion for $\mathrm{N}$ determination according to the Kjeldahl methodology (BREMNER, 1996).

For the assessment of $\mathrm{Ca}, \mathrm{Mg}, \mathrm{Fe}, \mathrm{Zn}, \mathrm{Mn}$, and $\mathrm{Cu}$ contents, plant material was ground and submitted to nitric-perchloric digestion, as described by Malavolta et al. (1997). The determination of nutrient contents was obtained by a flame atomic absorption spectrometer (PinAAcle 900F-Perkin Elmer).

Grain yield was obtained by collecting the ears from the two central rows of each plot. The ears were threshed and grains were weighed manually and transformed into $\mathrm{kg} \mathrm{ha}^{-1}$. The results were submitted to the analysis of variance. The means of treatments with $\mathrm{N}$ were compared by the Tukey's test at $5 \%$ probability.

\section{RESULTS AND DISCUSSION}

The different treatments did not provide an increase in stem diameter (Table 2). Similarly, VALDERRAMA et al. (2014) did not observe a significant effect of the stem diameter of the second internode when comparing conventional urea and polymer-coated urea. Dorneles et al. (2010) assessed $\mathrm{N}$ sources applied to the soil compared with foliar applications and observed significantly larger stems in treatments with application via soil, which was influenced by a split application in three plant growth stages (V4, V8, and V12), while leaf sources were applied only in the V6 stage. According to Fancelli and Dourado Neto (2000), the stem is a plant organ that has the function of storing solutes, which are distributed to the other organs in the course of its development. A variation in this parameter may influence plant development, but it is not a definitive factor to increase the final crop 
yield.

Table 2. Stem diameter and ear index of corn for the different $\mathrm{N}$ sources applied in the second crop corn. Chapadão do Sul, MS, Brazil, 2016

\begin{tabular}{lcc}
\hline Treatment & Stem diameter $(\mathrm{cm})$ & Ear index \\
\hline Control & $2.9 \mathrm{a}$ & $1.50 \mathrm{a}$ \\
Conventional urea & $3.1 \mathrm{a}$ & $1.49 \mathrm{a}$ \\
Split conventional urea & $3.2 \mathrm{a}$ & $1.58 \mathrm{a}$ \\
Polymer-coated urea & $3.3 \mathrm{a}$ & $1.25 \mathrm{a}$ \\
Split polymer-coated urea & $3.2 \mathrm{a}$ & $1.50 \mathrm{a}$ \\
Conventional urea + foliar N & $3.2 \mathrm{a}$ & $1.74 \mathrm{a}$ \\
Polymer-coated urea + foliar N & $3.3 \mathrm{a}$ & $1.66 \mathrm{a}$ \\
Foliar N & $3.3 \mathrm{a}$ & $1.41 \mathrm{a}$ \\
\hline $\mathrm{CV}(\%)$ & 5.9 & 5.95 \\
\hline
\end{tabular}

Means followed by the same letter do not differ from each other by the Tukey's test at 5\% significance level.

Nitrogen application in the different forms did not increase the ear index (Table 2). Soratto et al. (2010) observed similar results. FANCELLI and DOURADO NETO (2004) reported that in V4, the productive potential of a corn plant begins to be defined, as well as the process of floral differentiation. Nitrogen deficiency may interfere with the number of reproductive structures, affecting the number of ears.

Ear length, in all treatments (Table 3), differed from the control but did not differ from each other. The average ear length was $26.1 \%$ higher than the value obtained in the control. This assessment assists in identifying adverse development conditions when plant stress occurs, such as $\mathrm{N}$ deficiency, especially in the phenological stages that define production parameters in corn (V4, V8, and V12). According to MAGALHÃES et al. (1995), the nutrient deficiency at stages that define reproductive parameters can reduce the potential number of seeds, as well as ear size due to the number of eggs and ear size be defined in the V12 stage. Ear length is one of the characters that can directly interfere with yield (KAPPES et al., 2009). In fact, the longer the ear length is, the higher the potential number of grains per row in the ear (GOES et al., 2012) and the larger the grain size, increasing final yield.

Table 3. Ear length, number of grains per row, and number of rows per ear for different $\mathrm{N}$ sources applied to second crop corn. Chapadão do Sul, MS, Brazil, 2016

\begin{tabular}{lccc}
\hline Treatment & Ear length $(\mathrm{cm})$ & $\begin{array}{c}\text { Number of grains } \\
\text { per row }\end{array}$ & $\begin{array}{c}\text { Number of rows } \\
\text { per ear }\end{array}$ \\
\hline Control & $15.85 \mathrm{~b}$ & $40.16 \mathrm{~b}$ & $13.87 \mathrm{a}$ \\
Conventional urea & $19.95 \mathrm{a}$ & $41.91 \mathrm{a}$ & $14.72 \mathrm{a}$ \\
Split conventional urea & $19.80 \mathrm{a}$ & $41.92 \mathrm{a}$ & $15.00 \mathrm{a}$ \\
Polymer-coated urea & $20.35 \mathrm{a}$ & $41.99 \mathrm{a}$ & $14.70 \mathrm{a}$ \\
Split polymer-coated urea & $20.10 \mathrm{a}$ & $41.91 \mathrm{a}$ & $14.87 \mathrm{a}$ \\
Conventional urea + foliar N & $20.35 \mathrm{a}$ & $42.01 \mathrm{a}$ & $14.93 \mathrm{a}$ \\
Polymer-coated urea + foliar N & $19.90 \mathrm{a}$ & $42.08 \mathrm{a}$ & $15.25 \mathrm{a}$ \\
Foliar N & $19.45 \mathrm{a}$ & $41.99 \mathrm{a}$ & $15.00 \mathrm{a}$ \\
\hline $\mathrm{CV}(\%)$ & 4.59 & 1.92 & 4.39 \\
\hline
\end{tabular}

Means followed by the same letter do not differ from each other by the Tukey's test at 5\% significance level.

Similarly, the number of grains per row also differed from the control (Table 3), being, on average, $4.5 \%$ higher. It is clear the importance of $\mathrm{N}$ in the formation of this production component, but none of the used treatments was superior among them. For the component number of rows per ear, $\mathrm{N}$ use did not influence its values.

For plant height (Table 4), the treatment with the application of split conventional urea in two stages presented the highest values. In this treatment, the obtained plant height was $5.0 \%$ higher when compared to the average of the other treatments and $9.8 \%$ higher than that of the control. Although foliar nitrogen fertilization did not provide gains in plant height, DEUNER et al. (2008) obtained a $26 \%$ increase in the plant height of corn when comparing foliar $\mathrm{N}$ fertilization with the fertilization via soil. 
The highest first ear height (Table 4) was obtained by applying $\mathrm{N}$ in the V6 stage, being $9.9 \%$ above the average of the other treatments and $25.3 \%$ above the control. The increased height of corn plants was also observed by GOES et al. (2013) when using conventional urea, but with lower values for the first ear height.

Table 4. Plant height and first ear height for the different $\mathrm{N}$ sources applied in the second crop corn. Chapadão do Sul, MS, Brazil, 2016

\begin{tabular}{lcc}
\hline Treatment & Plant height $(\mathrm{m})$ & First ear height $(\mathrm{cm})$ \\
\hline Control & $1.73 \mathrm{~b}$ & $62.25 \mathrm{~b}$ \\
Conventional urea & $1.83 \mathrm{ab}$ & $78.00 \mathrm{a}$ \\
Split conventional urea & $1.90 \mathrm{a}$ & $73.00 \mathrm{ab}$ \\
Polymer-coated urea & $1.81 \mathrm{ab}$ & $75.00 \mathrm{ab}$ \\
Split polymer-coated urea & $1.81 \mathrm{ab}$ & $72.75 \mathrm{ab}$ \\
Conventional urea + foliar N & $1.82 \mathrm{ab}$ & $67.75 \mathrm{ab}$ \\
Polymer-coated urea + foliar N & $1.79 \mathrm{ab}$ & $68.50 \mathrm{ab}$ \\
Foliar N & $1.83 \mathrm{ab}$ & $68.75 \mathrm{ab}$ \\
\hline $\mathrm{CV}(\%)$ & 2.91 & 6.45 \\
\hline
\end{tabular}

Means followed by the same letter do not differ from each other by the Tukey's test at 5\% significance level.

Foliar N content and indices of chlorophyll

before nitrogen application (Table 5).

$\mathrm{a}, \mathrm{b}$, and total did not differ between treatments

Table 5. Nitrogen contents and indices of chlorophyll $a, b$, and total $(a+b)$ in corn leaves analyzed before application of treatments in the second crop corn. Chapadão do Sul, MS, Brazil, 2016

\begin{tabular}{lcccc}
\hline Treatment & $\mathrm{N}(\%)$ & Chlorophyll a & Chlorophyll b & Total Chlorophyll \\
\hline Control & $1.07 \mathrm{a}$ & $35.5 \mathrm{a}$ & $14.01000 \mathrm{a}$ & $49.56000 \mathrm{a}$ \\
Conventional urea & $1.04 \mathrm{a}$ & $36.8 \mathrm{a}$ & $14.95500 \mathrm{a}$ & $51.80500 \mathrm{a}$ \\
Split conventional urea & $1.12 \mathrm{a}$ & $35.7 \mathrm{a}$ & $12.82500 \mathrm{a}$ & $49.15000 \mathrm{a}$ \\
Polymer-coated urea & $1.19 \mathrm{a}$ & $36.3 \mathrm{a}$ & $14.19000 \mathrm{a}$ & $50.44000 \mathrm{a}$ \\
Split polymer-coated urea & $1.11 \mathrm{a}$ & $37.4 \mathrm{a}$ & $14.21500 \mathrm{a}$ & $51.85500 \mathrm{a}$ \\
Conventional urea + foliar N & $1.19 \mathrm{a}$ & $37.7 \mathrm{a}$ & $14.85500 \mathrm{a}$ & $52.12000 \mathrm{a}$ \\
Polymer-coated urea + foliar N & $1.14 \mathrm{a}$ & $37.2 \mathrm{a}$ & $13.93500 \mathrm{a}$ & $50.58500 \mathrm{a}$ \\
Foliar N & $1.21 \mathrm{a}$ & $36.4 \mathrm{a}$ & $14.17500 \mathrm{a}$ & $50.54500 \mathrm{a}$ \\
\hline $\mathrm{CV}(\%)$ & 20.59 & 4.06 & 11.75 & 5.83 \\
\hline
\end{tabular}

Means followed by the same letter do not differ from each other by the Tukey's test at 5\% significance level.

After $\mathrm{N}$ application (Table 6), foliar $\mathrm{N}$ content in the average of treatments was $115.0 \%$ higher than that observed in the control. When compared to the $\mathrm{N}$ contents considered as adequate (2.75-3.25\% of the dry matter) for corn, the results were higher than that observed for the standards, except for the control.

The treatments did not influence the indices of chlorophyll a, b, and total in corn leaves (Table 6). VALDERRAMA et al. (2014) also did not observe any effect of the application of coated and conventional urea in the chlorophyll index for corn crop sown in the first and second crop.

All the nutrients assessed in corn leaf (Table 7) were influenced by the applied treatments. Nitrogen application provided higher values of $\mathrm{Ca}$, $\mathrm{Mg}, \mathrm{Fe}, \mathrm{Zn}, \mathrm{Cu}$, and $\mathrm{Mn}$ in relation to the control, with values of $205,130,390,116,283$, and $159 \%$, respectively. This result evidences that $\mathrm{N}$ is in interaction with these nutrients in this phenological stage of the corn.

The values of critical levels for the results of leaf analysis in corn were compared with the nutritional values observed in the experiment (Table 8). Nitrogen application, regardless of the form or source, resulted in values for $\mathrm{N}, \mathrm{Ca}, \mathrm{Mg}, \mathrm{Fe}, \mathrm{Zn}, \mathrm{Cu}$, and $\mathrm{Mn}$ within the ranges considered as adequate for corn cultivation. However, for the control, only Fe, $\mathrm{Zn}$, and $\mathrm{Cu}$ were within the adequate range. For 100-grain weight (Table 9), the highest values were obtained with the use of polymer-coated urea, polymer-coated urea + foliar $\mathrm{N}$, and foliar $\mathrm{N}$. The average of these treatments allowed an increase in the 100 -grain weight of $6.1 \%$ in relation to the other treatments with $\mathrm{N}$ and $12.8 \%$ in relation to the control. SOUZA et al. (2011) also did not verify the effect of the use of different solid sources and application times of $\mathrm{N}$ in the 100-grain weight of 
corn. In addition, when assessing conventional urea compared to polymer-coated urea under Cerrado conditions in the state of Minas Gerais, QUEIROZ et al. (2011) did not observe significance for 100grain weight. According to SILVA et al. (2006), 100-grain weight is an important parameter for the study of yield in corn since a higher yield can be obtained from the same number of fertilized eggs only increasing the reserves accumulated in the grains.

Table 6. Nitrogen contents and indices of chlorophyll $a, b$, and total $(a+b)$ in corn leaves analyzed after the N application for the different sources used in the second crop corn. Chapadão do Sul, MS, Brazil, 2016

\begin{tabular}{lcccc}
\hline Treatment & N $(\%)$ & Chlorophyll a & Chlorophyll b & Total Chlorophyll \\
\hline Control & $1.89 \mathrm{~b}$ & $37.98250 \mathrm{a}$ & $20.60250 \mathrm{a}$ & $58.56750 \mathrm{a}$ \\
Conventional urea & $4.08 \mathrm{a}$ & $38.20750 \mathrm{a}$ & $20.94750 \mathrm{a}$ & $59.49750 \mathrm{a}$ \\
Split conventional urea & $3.87 \mathrm{a}$ & $39.14250 \mathrm{a}$ & $21.92500 \mathrm{a}$ & $61.14500 \mathrm{a}$ \\
Polymer-coated urea & $3.86 \mathrm{a}$ & $38.63500 \mathrm{a}$ & $21.84500 \mathrm{a}$ & $60.72750 \mathrm{a}$ \\
Split polymer-coated urea & $4.25 \mathrm{a}$ & $38.39000 \mathrm{a}$ & $20.90750 \mathrm{a}$ & $59.30250 \mathrm{a}$ \\
Conventional urea + foliar N & $4.04 \mathrm{a}$ & $38.53250 \mathrm{a}$ & $20.98750 \mathrm{a}$ & $59.55250 \mathrm{a}$ \\
Polymer-coated urea + foliar N & $4.28 \mathrm{a}$ & $39.22500 \mathrm{a}$ & $21.48250 \mathrm{a}$ & $59.68000 \mathrm{a}$ \\
Foliar N & $4.07 \mathrm{a}$ & $38.31750 \mathrm{a}$ & $21.26750 \mathrm{a}$ & $59.58250 \mathrm{a}$ \\
\hline $\mathrm{CV}(\%)$ & 15.87 & 2.09 & 6.40 & 3.05 \\
\hline
\end{tabular}

Means followed by the same letter do not differ from each other by the Tukey's test at $5 \%$ significance level.

Table 7. Contents of $\mathrm{Ca}, \mathrm{Mg}, \mathrm{Fe}, \mathrm{Zn}, \mathrm{Cu}$, and $\mathrm{Mn}$ in corn leaves analyzed after $\mathrm{N}$ applications for different sources used in the second crop corn. Chapadão do Sul, MS, Brazil, 2016

\begin{tabular}{lcccccc}
\hline Treatment & $\mathrm{Ca}$ & $\mathrm{Mg}$ & $\mathrm{Fe}$ & $\mathrm{Zn}$ & $\mathrm{Cu}$ & $\mathrm{Mn}$ \\
\hline Control & $0.22 \mathrm{c}$ & $0.27 \mathrm{c}$ & $154.58 \mathrm{~b}$ & $30.36 \mathrm{c}$ & $6.65 \mathrm{~b}$ & $32.23 \mathrm{c}$ \\
Conventional urea & $0.40 \mathrm{a}$ & $0.43 \mathrm{~b}$ & $184.24 \mathrm{a}$ & $62.65 \mathrm{a}$ & $9.60 \mathrm{a}$ & $45.01 \mathrm{bc}$ \\
Split conventional urea & $0.40 \mathrm{a}$ & $0.47 \mathrm{ab}$ & $189.77 \mathrm{a}$ & $59.56 \mathrm{a}$ & $9.40 \mathrm{a}$ & $51.43 \mathrm{~b}$ \\
Polymer-coated urea & $0.29 \mathrm{bc}$ & $0.48 \mathrm{ab}$ & $192.87 \mathrm{a}$ & $49.31 \mathrm{~b}$ & $9.25 \mathrm{a}$ & $51.17 \mathrm{~b}$ \\
Split polymer-coated urea & $0.28 \mathrm{bc}$ & $0.44 \mathrm{ab}$ & $194.79 \mathrm{a}$ & $48.95 \mathrm{~b}$ & $9.25 \mathrm{a}$ & $50.32 \mathrm{~b}$ \\
Conventional urea + foliar N & $0.33 \mathrm{ab}$ & $0.51 \mathrm{ab}$ & $197.00 \mathrm{a}$ & $59.89 \mathrm{a}$ & $7.75 \mathrm{ab}$ & $46.42 \mathrm{bc}$ \\
Polymer-coated urea + foliar N & $0.30 \mathrm{~b}$ & $0.47 \mathrm{ab}$ & $199.32 \mathrm{a}$ & $62.25 \mathrm{a}$ & $7.85 \mathrm{ab}$ & $52.67 \mathrm{~b}$ \\
Foliar N & $0.29 \mathrm{bc}$ & $0.54 \mathrm{a}$ & $201.46 \mathrm{a}$ & $52.80 \mathrm{~b}$ & $9.90 \mathrm{a}$ & $70.10 \mathrm{a}$ \\
\hline $\mathrm{CV}(\%)$ & 11.98 & 10.56 & 5.54 & 7.34 & 11.95 & 13.31 \\
\hline
\end{tabular}

Means followed by the same letter do not differ from each other by the Tukey's test at $5 \%$ significance level.

Table 8. Corn leaf analysis of corn grown under different sources and forms of $\mathrm{N}$ application and comparison with the limits established as adequate for the crop (BULL, 1993)1. Chapadão do Sul, MS, Brazil, 2016

\begin{tabular}{|c|c|c|c|c|c|c|c|}
\hline & $\mathrm{N}$ & $\mathrm{Ca}$ & $\mathrm{Mg}$ & $\mathrm{Fe}$ & $\mathrm{Zn}$ & $\mathrm{Cu}$ & $\mathrm{Mn}$ \\
\hline & \multicolumn{3}{|c|}{---------------g kg } & \multicolumn{4}{|c|}{ 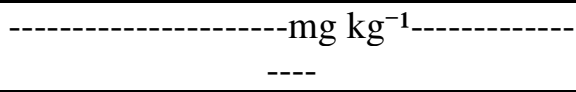 } \\
\hline Reference range $^{1}$ & $2.75-3.25$ & $\begin{array}{c}0.23- \\
0.40\end{array}$ & $\begin{array}{c}0.15- \\
0.40\end{array}$ & $50-250$ & $15-50$ & $6-20$ & $42-150$ \\
\hline Control & 1.89 & 0.22 & 0.27 & 154.58 & 30.36 & 6.65 & 32.23 \\
\hline Conventional urea & 4.08 & 0.40 & 0.43 & 184.24 & 62.65 & 9.60 & 45.01 \\
\hline Split conventional urea & 3.87 & 0.40 & 0.47 & 189.77 & 59.56 & 9.40 & 51.43 \\
\hline Polymer-coated urea & 3.86 & 0.29 & 0.48 & 192.87 & 49.31 & 9.25 & 51.17 \\
\hline Split polymer-coated urea & 4.25 & 0.28 & 0.44 & 194.79 & 48.95 & 9.25 & 50.32 \\
\hline Conventional urea + foliar $\mathrm{N}$ & 4.04 & 0.33 & 0.51 & 197.00 & 59.89 & 7.75 & 46.42 \\
\hline $\begin{array}{l}\text { Polymer-coated urea }+ \text { foliar } \\
\mathrm{N}\end{array}$ & 4.28 & 0.30 & 0.47 & 199.32 & 62.25 & 7.85 & 52.67 \\
\hline Foliar N & 4.07 & 0.29 & 0.54 & 201.46 & 52.80 & 9.90 & 70.10 \\
\hline
\end{tabular}

Means followed by the same letter do not differ from each other by the Tukey's test at 5\% significance level. 
Corn grain yield was influenced by $\mathrm{N}$ application regardless of the form or source (Table 9). The average of treatments with $\mathrm{N}$ provided a $9.2 \%$ increase in corn grain yield, which represent $668 \mathrm{~kg}$. SOUZA and SORATTO (2006) assessed the effect of $\mathrm{N}$ sources (urea and Entec $26^{\circledR}$ ) and four topdressing $\mathrm{N}$ doses $(0,30,60$, and $120 \mathrm{~kg}$ $\mathrm{ha}^{-1}$ ) when plants had four expanded leaves and did not find a significant difference between factors, concluding that the $\mathrm{N}$ sources did not differ from each other for grain yield.

Table 9. Average values of 100-grain weight and grain yield as a function of $\mathrm{N}$ application for different sources used in the second crop corn. Chapadão do Sul, MS, Brazil, 2016

\begin{tabular}{lcc}
\hline Treatment & 100-grain weight $(\mathrm{g})$ & Yield $\left(\mathrm{kg} \mathrm{ha}^{-1}\right)$ \\
\hline Control & $29.35 \mathrm{~b}$ & $7.241 .71 \mathrm{~b}$ \\
Conventional urea & $31.25 \mathrm{ab}$ & $7.894 .99 \mathrm{a}$ \\
Split conventional urea & $31.05 \mathrm{ab}$ & $7.901 .90 \mathrm{a}$ \\
Polymer-coated urea & $33.00 \mathrm{a}$ & $7.928 .27 \mathrm{a}$ \\
Split polymer-coated urea & $32.93 \mathrm{a}$ & $7.895 .25 \mathrm{a}$ \\
Conventional urea + foliar N & $31.27 \mathrm{ab}$ & $7.864 .45 \mathrm{a}$ \\
Polymer-coated urea + foliar N & $32.85 \mathrm{a}$ & $7.985 .42 \mathrm{a}$ \\
Foliar N & $33.65 \mathrm{a}$ & $7.898 .77 \mathrm{a}$ \\
\hline $\mathrm{CV}(\%)$ & 4.92 & 4.07 \\
\hline
\end{tabular}

Means followed by the same letter do not differ from each other by the Tukey's test at 5\% significance level.

\section{CONCLUSIONS}

Nitrogen in the form of conventional urea, polymer-coated urea, and foliar $\mathrm{N}$ in a single or split application for second crop corn does not result in distinct benefits for the crop. Thus, attention should be paid to the product commercialization, which has different prices for the different forms of nitrogen, but without results, for example, in grain yield, which in fact will compose the producer income.

The applied nitrogen form and mode of application were positive only to increase the contents of $\mathrm{Ca}, \mathrm{Mg}, \mathrm{Zn}$, and $\mathrm{Mn}$ in the leaves of second crop corn.

Calcium was favored by the use of conventional urea and split conventional urea, $\mathrm{Mg}$ and $\mathrm{Mn}$ were only benefited by foliar $\mathrm{N}$ application, and $\mathrm{Zn}$ was benefited by the use of conventional urea, split conventional urea, conventional urea + foliar $\mathrm{N}$, and polymer-coated urea + foliar $\mathrm{N}$.

Importantly, corn hybrids available for cultivation may respond differently to nitrogen fertilization, so all the conclusions of this research apply to the $\mathrm{P} 3456 \mathrm{H}$ corn hybrid.

\section{ACKNOWLEDGEMENTS}

The authors would like to thank CAPES (Coordination for the Improvement of Higher Education Personnel), CNPq (National Council for Scientific Technological Development), FUNDECT-MS (Foundation for the Support and Development of Education, Science and Technology from the State of Mato Grosso do Sul) for their financial support.

RESUMO: O manejo da adubação, principalmente a nitrogenada, é um dos fatores que afetam mais diretamente a produtividade de grãos de milho. A dinâmica do nitrogênio no solo é bastante complexa e a principal fonte atualmente utilizada na produção do milho, a ureia, em sua forma convencional, sofre perdas intensas, principalmente por volatilização e lixiviação. Assim, o objetivo deste trabalho foi avaliar o efeito de formas, fontes e épocas de aplicação de nitrogênio na cultura do milho segunda safra. O experimento foi conduzido no ano de 2016 na Fundação Chapadão, no município de Chapadão do Sul, MS, Brasil. Foram utilizadas as fontes ureia convencional, ureia revestida com polímero e $\mathrm{N}$ foliar (8 tratamentos), sendo eles: testemunha (sem adição de N); ureia convencional (todo aplicado no estádio V3) e (parcelada em V3 e V6); ureia com polímero (todo em V3) e (parcelada em V3 e V6); Ureia convencional + $\mathrm{N}$ foliar (ureia convencional em V6 e foliar em pré-florada); Ureia com polímero $+\mathrm{N}$ foliar (ureia com polímero em V6 e foliar em préflorada) e $\mathrm{N}$ foliar (parcelado em V6 e pré-florada). Foram avaliados o diâmetro de colmo, índice de espiga, comprimento de espiga, número de grãos por fileira, número de fileiras por espiga, altura de plantas, altura de inserção da primeira espiga, índice de clorofila foliar, índice de $\mathrm{N}$ foliar, valores foliares de $\mathrm{Ca}, \mathrm{Mg}, \mathrm{Fe}, \mathrm{Zn}, \mathrm{Mn}$ e Cu, massa de 100 grãos e produtividade de grãos. A aplicação do nitrogênio na forma de ureia convencional, 
ureia com polímeros e foliar, de forma única ou parcelada, para o milho segunda safra, não resulta em benefícios distintos para a cultura. Assim, deve-se ficar atento a comercialização do produto, que tem preços estabelecidos de acordo com as formas do nitrogênio, mas sem resultado, por exemplo, na produtividade de grãos, que irá de fato compor a renda do produtor. A forma do nitrogênio aplicado e o modo de aplicação foram positivos apenas para aumentar os teores de $\mathrm{Ca}, \mathrm{Mg}, \mathrm{Zn}$ e $\mathrm{Mn}$ nas folhas do milho segunda safra. O Ca foi favorecido pelo uso da ureia convencional e convencional parcelada, o $\mathrm{Mg}$ e o $\mathrm{Mn}$ foram beneficiados apenas pela aplicação de $\mathrm{N}$ foliar, enquanto o $\mathrm{Zn}$ foi beneficiado pelo uso da ureia convencional, convencional parcelada, convencional $+\mathrm{N}$ foliar e ureia com polímero $+\mathrm{N}$ foliar.

PALAVRAS-CHAVES: Adubação. Fontes de N. Aplicação foliar.

\section{REFERENCES}

BIESDORF, E. M.; BIESDORF, E. M.; TEIXEIRA, M. F. F.; DIETRICH, O. H.; PIMENTEL, L. D.; ARAUJO, C. Métodos de aplicação de nitrogênio na cultura do milho em solo de cerrado. Revista de Agricultura Neotropical, v. 3, n. 1, p. 44-50, 2016. https://doi.org/10.32404/rean.v3i1.805

BÜLL, L. T. Nutrição mineral do milho. In: BÜLL, L. T.; CANTARELA, H. (Ed.). Cultura do milho: fatores que afetam a produtividade. Piracicaba: Associação Brasileira para Pesquisa da Potassa e do Fostato, 1993. p. 63-145.

BREMNER, J. M. Nitrogen-total. In: SPARTS, D. L. (Ed.) Methods of gril analysis Part 3: Chemical Methods. Madison: Soil Science Society of America, 1996. p. 1085- 1121.

CANTARELLA, H.; MARCELINO, R. Fontes alternativas de nitrogênio para a cultura do milho. Informações Agronômicas, v. 1, n. 122, p. 12-14, 2008.

CONAB - Companhia Nacional de Abastecimento. Acompanhamento da safra brasileira de grãos. 5 ed. Brasília: Conab, 2018. 140 p.

CUNHA, F. F.; MAGALHÃES, F. F.; CASTRO, M. A. Métodos para estimativa da evapotranspiração de referência para Chapadão do Sul - MS. Engenharia na agricultura, v. 21 n. 2, p. 159-172, 2013. https://doi.org/10.13083/1414-3984.v21n02a06

DEUNER, S.; NASCIMENTO, R.; FERREIRA, L. S.; BADINELLI, P. G.; KERBER, R. S. Adubação foliar e via solo de nitrogênio em plantas de milho em fase inicial de desenvolvimento. Ciência e Agrotecnologia, v. 32, n. 5, p. 1359-1365, 2008. https://doi.org/10.1590/s1413-70542008000500001

DORNELES, J. G. L.; SILVA, A. M.; SANTANA, J. S.; RUVIARO, C. Avaliação da produtividade do milho em resposta a adubação de nitrogênio em cobertura via solo e via foliar. In: CONGRESSO NACIONAL DE MILHO E SORGO, 28., 2010, Goiânia. Anais...Goiânia: Associação Brasileira de Milho e Sorgo, 2010. p. 110.

FANCELLI, A. L.; DOURADO NETO, D. Produção de milho. 2. ed. Guaíba: Agropecuária, 2004. 360 p.

FANCELLI, A. L.; DOURADO NETO, D. Ecofisiologia e Fenologia. In: FANCELLI, A. L.; DOURADO NETO, D. Produção de milho. Guaíba: Agropecuária, 2000. p. 21-54.

FARINELLI, R.; LEMOS, L. B. Produtividade e eficiência agronômica do milho em função da adubação nitrogenada e manejos do solo. Revista Brasileira de Milho e Sorgo, v. 9, n. 2, p. 135-146, 2010. https://doi.org/10.18512/1980-6477/rbms.v9n2p135-146 
FONTOURA, S. M. V.; BAYER, C. Ammonia volatilization in no-till system in the south-central region of the State of Paraná, Brazil. Revista Brasileira de Ciência do Solo, v. 34, n. 5, p. 1677-1684, 2010. https://doi.org/10.1590/s0100-06832010000500020

GAZOLA, D.; ZUCARELI, C.; SILVA, R. R.; FONSECA, I. C. B. Aplicação foliar de aminoácidos e adubação nitrogenada de cobertura na cultura do milho safrinha. Revista Brasileira de Engenharia Agrícola e Ambiental, v. 18, n. 7, p. 700-707, 2014. https://doi.org/10.1590/s1415-43662014000700005

GOES, R. J.; RODRIGUES, R. A. F.; ARF, O.; VILELA, R. G. Nitrogênio em cobertura para o milho (Zea mays L.) em sistema de plantio direto na safrinha. Revista Brasileira de Milho e Sorgo, v. 11, n. 2, p.169-177, 2012. https://doi.org/10.18512/1980-6477/rbms.v11n2p169-177

GOES, R. J.; RODRIGUES, R. A. F.; TAKASU, A. T.; ARF, O. Características agronômicas e produtividade do milho sob fontes e doses de nitrogênio em cobertura no inverno. Revista Brasileira de Milho e Sorgo, v. 12, n. 3, p. 250-259, 2013. https://doi.org/10.18512/1980-6477/rbms.v12n3p250-259

GOULDING, K.; JARVIS, S.; WHITMORE A. Optimizing nutrient management for farm systems. Philosophical Transactions of the Royal Society B: Biological Sciences, v. 363, n. 1491, p. 667-680, 2008. https://doi.org/10.1098/rstb.2007.2177

KAPPES, C.; CARVALHO, M. A. C. DE; YAMASHITA, O. M.; SILVA, J. A. N. da. Influência do nitrogênio no desempenho produtivo do milho cultivado na segunda safra em sucessão à soja. Pesquisa Agropecuária Tropical, v. 39, n. 3, p. 251-259, 2009.

KARLEN, D. L.; KRAMER, L. A.; LOGSDON, S. D. Field-scale nitrogen balances associated with long-term continuous corn production. Agronomy Journal, v. 90, n. 5, p. 644-650, 1998.

https://doi.org/10.2134/agronj1998.00021962009000050013x

LUNELLI, I. E.; MORATELLI, C. A.; PRIMO, M.; OLIVEIRA, R. S.; PRIOR, M. Avaliação de componentes da planta do milho sobre diferentes épocas de aplicação de nitrogênio em sucessão a diferentes coberturas de solo. Revista Brasileira de Tecnologia Aplicada nas Ciências Agrárias, v. 3, n. 1, p. 123-128, 2010.

MA, B. L.; WU, T. Y.; SHANG, J. On-farm comparison of variable rates of nitrogen with uniform application to maize on canopy reflectance, soil nitrate and grain yield. Journal of Plant Nutrition and Soil Science, v. 177, n. 2, p. 216-226. 2014. https://doi.org/10.1002/jpln.201200338

MAGAlHÃES, P. C.; DURÃES, F. O. M.; PAIVA, E. Fisiologia da planta de milho. Sete Lagoas: EmbrapaCNPMS, 1995. 27 p. (Embrapa-CNPMS. Circular Técnica, 20).

MALAVOLTA, E.; VITTI, G. C.; OLIVEIRA, S. A. Avaliação do estado nutricional das plantas: Princípios e aplicações. 2. ed. Piracicaba: Associação Brasileira da Potassa e do Fosfato, 1997. 319 p.

MEDINA C. L.; OBREZA T. A.; SARTAIN; J. B., ROUSE R. E. Nitrogen release patterns of a mixed controlled-release fertilizer and its components. Hort Technology, v. 18, n. 3, p. 475-480, 2008.

https://doi.org/10.21273/horttech.18.3.475

QUEIROZ, A. M.; SOUZA, C. H. E.; MACHADO, V. J.; LANA, R. M. Q.; KORNDORFER, G. H.; SILVA, A. A. Avaliação de diferentes fontes e doses de nitrogênio na adubação da cultura do milho (Zea mays L.). Revista Brasileira de Milho e Sorgo, v. 10, n. 3, p. 257-266, 2011. https://doi.org/10.18512/19806477/rbms.v10n3p257-266

ROSSETTI, K. V.; CENTURION, J. F. Tillage systems and hydro-physical attributes of an Oxisol cultivated with maize. Revista Brasileira de Engenharia Agrícola Ambiental, v. 17, n. 5, p. 472-479, 2013. http://dx.doi.org/10.1590/S1415-43662013000500002 
SAIKIA, S. P.; JAIN, V. Biological nitrogen fixation with non-legumes: an achievable target or a dogma. Current Science, v. 92, n. 3, p. 317-322, 2007.

SILVA, A. D.; VITORINO, A. C. T.; SOUZA, L. C. F. de; GONÇALVES, M. C.; ROSCOE, R. Culturas antecessoras e adubação nitrogenada na cultura do milho, em sistema de plantio direto. Revista Brasileira de Milho e Sorgo, v. 5, n. 1, p. 75-88, 2006. https://doi.org/10.18512/1980-6477/rbms.v5n1p75-88

SORATTO, R. P.; PEREIRA, M.; COSTA, T. A. M; LAMPERT, V. N. Fontes alternativas e doses de nitrogênio no milho safrinha em sucessão à soja. Revista Ciência Agronômica, v. 41, n. 4, p. 511-518, 2010. https://doi.org/10.1590/s1806-66902010000400002

SOUZA, E. F. C.; SORATTO, R. P. Efeito de fontes e doses de nitrogênio em cobertura, no milho safrinha, em plantio direto. Revista Brasileira de Milho e Sorgo, v. 5, n. 3, p. 395-405, 2006.

https://doi.org/10.18512/1980-6477/rbms.v5n3p395-405

SOUZA, A. S.; BUZETTI, S.; TEIXEIRA FILHO, M. C. M.; ANDREOTTI, M.; SÁ, M. E.; ARF, O. Adubação nitrogenada na cultura do milho safrinha irrigado em plantio direto. Bragantia, v. 70, n. 2, p. 447454, 2011. https://doi.org/10.1590/s0006-87052011000200028

VALDERRAMA, M.; BUZETTI, S.; TEIXEIRA FILHO, M. C. M.; BENETT, C. G. S.; ANDREOTTI, M. Adubação nitrogenada na cultura do milho com ureia revestida por diferentes fontes de polímeros. Ciências Agrárias, v. 35, n. 2, p. 659-670, 2014. https://doi.org/10.5433/1679-0359.2014v35n2p659

WANG, Z.; GAO, J.; MA, B. L. Concurrent improvement in maize yield and nitrogen use efficiency with integrated agronomic management strategies. Agronomy journal, v. 106, n. 4, p. 1243-1250, 2014. https://doi.org/10.2134/agronj13.0487 